GEOHYDROLOGY AND SUSCEPTIBILITY OF MAJOR AQUIFERS

TO SURFACE CONTAMINATION IN ALABAMA; AREA 1

by C. R. Bossong and Wiley F. Harris

U.S. GEOLOGICAL SURVEY

Water-Resources Investigations Report 87-4068

Prepared in cooperation with the

ALABAMA DEPARTMENT OF ENVIRONMENTAL MANAGEMFNT

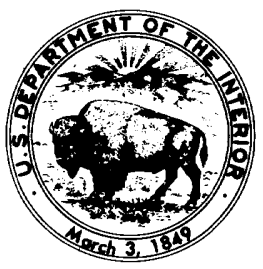

Tuscaloosa, Alabama 


\author{
DEPARTMENT OF THE INTERIOR \\ DONALD PAUL HODEL, Secretary \\ U.S. GEOLOGICAL SURVEY \\ Dallas L. Peck, Director
}

For additional information write to:

District Chief

U.S. Geological Survey

52019 th Avenue

Tuscaloosa, Alabama 35401
Copies of this report can be purchased from:

U.S. Geological Survey Books and Open-File Reports Box 25425, Federal Center Building 81

Denver, Colorado 80225 
Abstract..........................................

Introduction........................................

Purpose and scope..................................

Location and extent of the area........................

Physical features...................................

Previous investigations..............................

Geology ..............................................

structure....................................

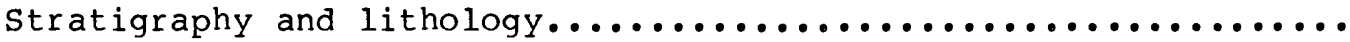

Ordovician, Silurian, and Devonian systems..............

Mississippian system............................

Fort Payne Chert..............................

Tuscumbia Limestone..........................

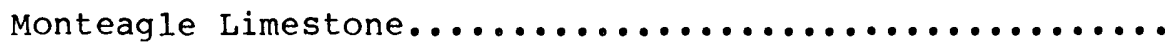

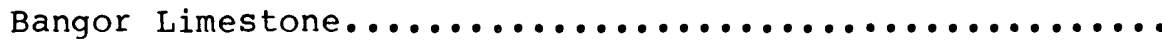

Pennsylvanian system .............................

Cretaceous system...............................

Hydrology ..........................................

Major aquifers and their water-bearing characteristics.........

Tuscumbia-Fort Payne aquifer.......................

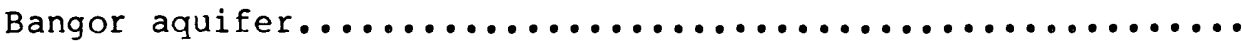

Tuscaloosa aquifer...............................

Potentiometric surfaces................................

Factors controlling ground-water movement and occurrence........

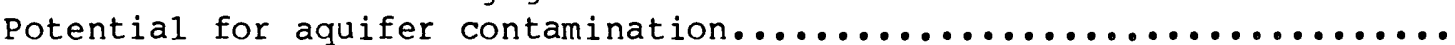

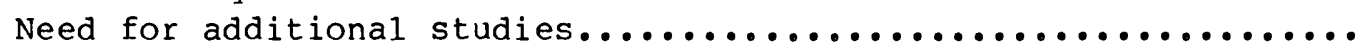

Summary and conclusions...................................

Selected references................................... 


\section{ILLUSTRATIONS}

Plate 1. Potentiometric map for major aquifers showing areas susceptible to contamination and locations of public-supply wells....................... in back

Figure 1. Map showing location of study area.................. 3

2. Physical features of the study area................. 4

3. Generalized surface geology of the study area........... 8

4. Generalized sub-surface geology and stratigraphic relations. 9

5. Hydrographs of daily discharge for the Paint Rock River and the flint River............................ 12

TABLES

Table 1. Streamflow characteristics for selected streams........... 24

2. Records of public supply wells and springs in the study area. 25

3. Summary of potentiometric surface data base by county....... 34 


\section{CONVERSION FACTORS}

For use of readers who prefer to use metric (International system) units, conversion factors for inch-pound units used in this report are listed below:

\begin{tabular}{|c|c|c|}
\hline Multiply inch-pound unit & $\underline{\text { By }}$ & To obtain metric unit \\
\hline inch (in.) & 25.4 & millimeter $(\mathrm{mm})$ \\
\hline foot $(f t)$ & 0.3048 & meter (m) \\
\hline mile $(\mathrm{mi})$ & 1.609 & kilometer $(\mathrm{km})$ \\
\hline $\begin{array}{l}\text { cubic foot per second } \\
\text { per square mile } \\
{\left[(\mathrm{ft} 3 / \mathrm{s}) / \mathrm{mi}^{2}\right]}\end{array}$ & 0.01093 & $\begin{array}{l}\text { cubic meter per second } \\
\text { per square kilometer } \\
{\left[\left(\mathrm{m}^{3} / \mathrm{s}\right) / \mathrm{km}^{2}\right]}\end{array}$ \\
\hline $\begin{array}{l}\text { gallon per minute } \\
\text { (gal/min) }\end{array}$ & 0.06308 & $\begin{array}{c}\text { liter per second } \\
(\mathrm{L} / \mathrm{s})\end{array}$ \\
\hline $\begin{array}{l}\text { million gallons per day } \\
\text { (Mgal/d) }\end{array}$ & 0.04381 & $\begin{array}{c}\text { cubic meter per second } \\
\left(\mathrm{m}^{3} / \mathrm{s}\right)\end{array}$ \\
\hline
\end{tabular}

Sea level: In this report "sea level" refers to the National Geodetic Vertical Datum of 1929 (NGVD of 1929)--a geodetic datum derived from a general adjustment of the first-order level nets of both the United States and Canada, formerly called "Mean Sea Level of 1929." 


\title{
GEOHYDROLOGY AND SUSCEPTIBILITY OF MAJOR AQUIFERS TO SURFACE CONTAMINATION IN ALARAMA; AREA 1
}

\author{
by C. R. Bossong and Wiley F. Harris
}

\section{ABSTRACT}

The U.S. Geological Survey, in cooperation with the Alabama nepartment of Environmental Management, is conducting a series of geohydrologic studies to delineate the major aquifers and their susceptibility to contamination in Alabama. This report delineates and describes the geohydrology and susceptibility of the major aquifers to contamination in Area 1--Colbert, Franklin, Lauderdale, Lawrence, Limestone, Madison, and Morgan Counties. Most of the area is underlain by a Mississippian carbonate sequence that includes two major aquifers, the Tuscumbia-Fort Payne aquifer and the Bangor aquifer. A third major aquifer, the Tuscaloosa aquifer of Cretaceous age, occurs in the southwest part of the area.

The Mississippian carbonate aquifers are the Tuscumbia-Fort Payne aquifer which includes mostly Tuscumbia Limestone and the Fort Payne Chert, and a small area of the Monteagle Limestone, and the Bangor aquifer which includes the Bangor Limestone and Hartselle Sandstone. Both of these aquifers possess highly-variable secondary porosity and permeability related to fractures that have been enlarged, sometimes to cavernous proportions, due to solution processes. The Tuscaloosa aquifer consists of the Tuscaloosa Group, an unconsolidated clastic deposit that has relatively uniform primary porosity and permeability. Significant quantities of ground water are available from each of the aquifers. Water levels at nearly 2,000 wells indicate that, for each aquifer, general ground-water movement is from topographically high to low areas.

Each of the aquifers is recharged throughout its outcrop in the study area and is susceptible to contamination within the outcrop. Generalized topographic settings such as closed-contour depressions are identified as areas that are highly susceptible to contamination. Specific features such as sinkholes also are identified as extremely susceptible to contamination. 


\section{INTRODUCTION}

The Alabama Department of Environmental Management (ADEM) is developing a comprehensive program to protect aquifers in Alabama from surface contamination. The aquifers are defined by the U.S. Environmental Protection Agency (EPA) as "Class I and II" aquifers (U.S. Environmental Protection Agency, 1984). The U.S. Geological survey (USGS), in cooperation with ADEM, is conducting a series of geohydrologic studies to delineate the major aquifers in Alabama, their recharge areas, and areas susceptible to contamination. This report summarizes these factors for major aquifers in Area 1--Colbert, Franklin, Lauderdale, Lawrence, Limestone, Madison, and Morgan Counties (see plate 1).

\section{Purpose and Scope}

The purpose of this report is to describe the geohydrology of the major aquifers and their susceptibility to contamination from the surface. Geologic and hydrologic data compiled as part of previous investigations provided about 90 percent of the data used to evaluate the major aquifers in the area. All wells used for municipal and rural public water supplies were inventoried, and water levels were measured where possible. Data on water use were compiled during the well inventory. Water-level data were used to compile generalized potentiometric maps of the aquifers. Areas susceptible to contamination from the surface were delineated partly from topographic maps and other available data, and partly from field investigation.

\section{Location and Extent of the Area}

The study area is in north-central and northwestern Alabama. It comprises about 4,500 square miles, mostly in the Tennessee River drainage basin, but also includes a small portion in the Tombigbee River drainage basin (fig. 1). The area is currently experiencing steady population growth of approximately 20 percent per year that is related to industrialization (U.S. Department of Commerce, 1984a). Although the trend towards industrialization is prevalent, the area is also a significant agricultural region. The altitudel/ of the land surface ranges from about 440 to about 1,840 feet above sea level; however, local relief is rarely greater than about 300 feet.

\section{Physical Features}

Parts of the Interior Low Plateaus, Appalachian Plateaus, and Coastal Plain physiographic provinces are in the area (Fenneman, 1938). Each province has been sub-divided into sections, many of which are present in the study area. Most of the study area is in the Highland Rim section of the Interior Low Plateaus. A small part in the east and south part of the area is in the Interior Low plateaus and a smaller part in the west and south, where the province boundary is poorly defined, is in the Coastal Plain (fig. 2).

1/ Altitudes, as used in this report, refer to distance above sea level. 


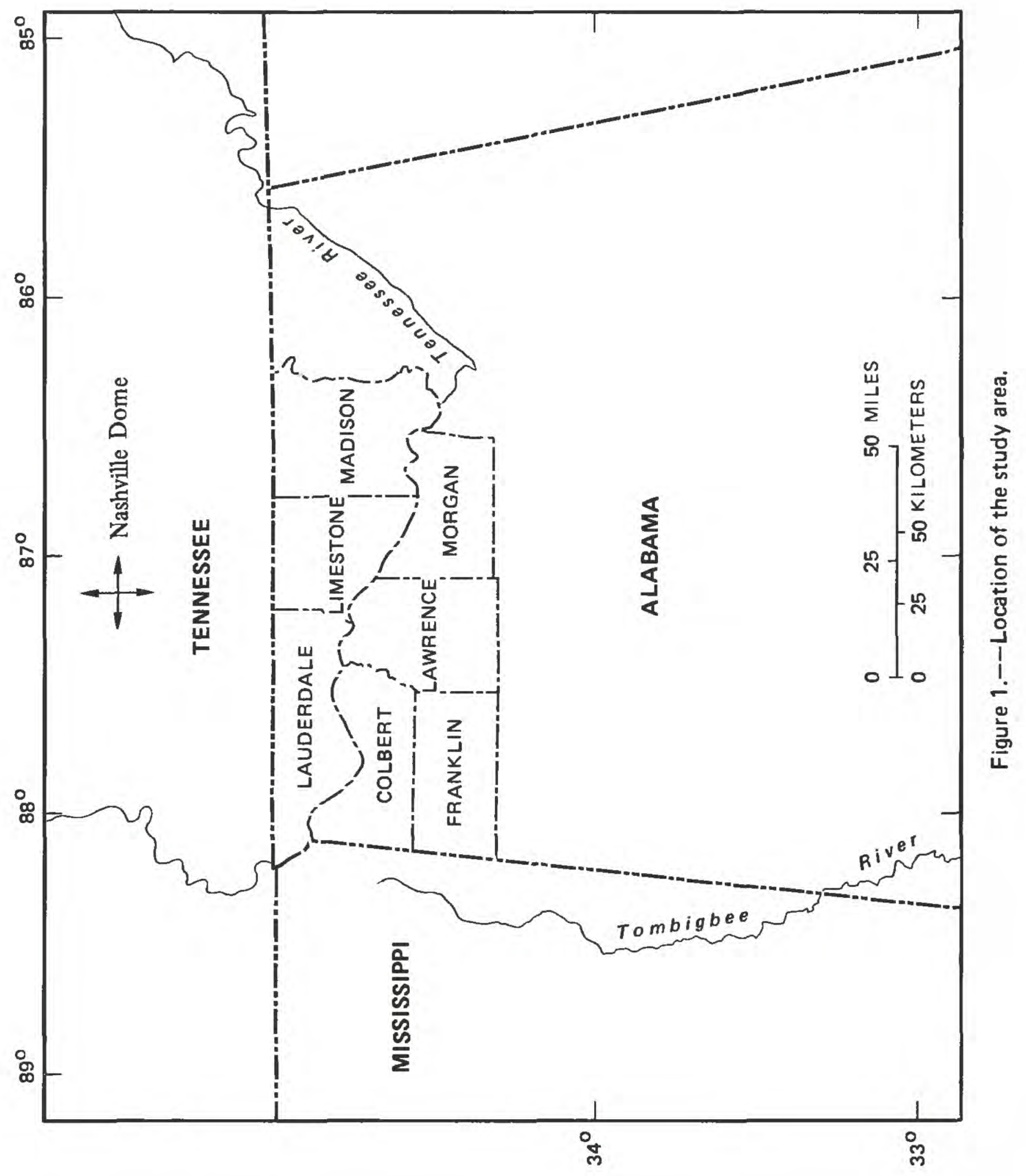




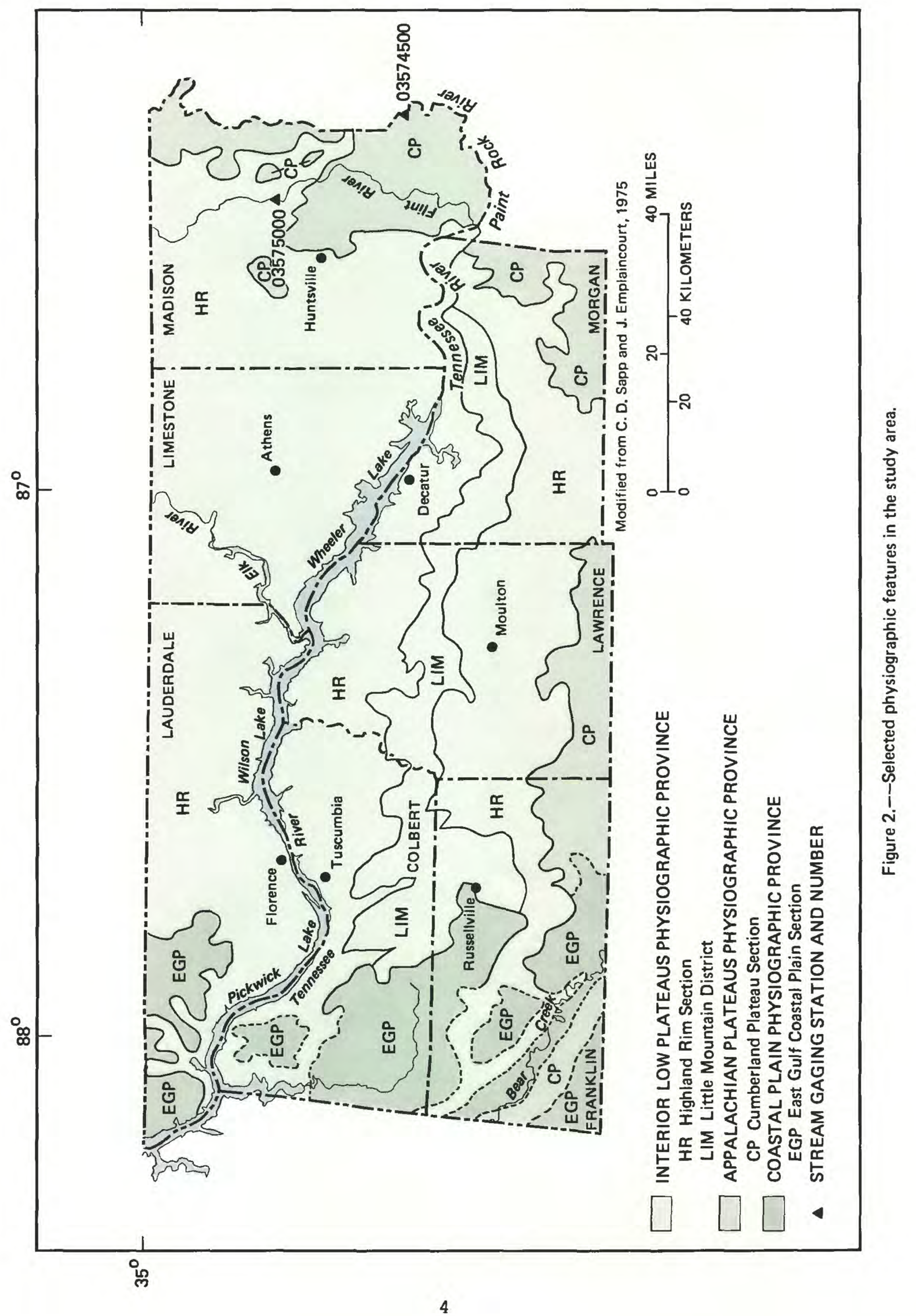


The Highland Rim section of the Interior Low Plateaus is typically an area of low relief and flat to rolling topography. Another section of the Interior Low Plateaus, Little Mountain, is present south of the Tennessee River (fig. 2); it is a low escarpment that bisects the Highland Rim section. To the north of Little Mountain altitudes are lower and bedrock is somewhat older than to the south.

The Cumberland Plateau section of the Appalachian Plateaus is typically an area of relatively high relief due to sub-mature dissection. The dissection in the study area, especially north of the Tennessee River, is more advanced than typical and the area consists of a series of steep sided hills or mountains. This type of terrain is common in eastern Madison county (fig. 2). South of the Tennessee River the section is more typical.

The East Gulf Coastal plain section of the Coastal Plain province in the study area is referred to as the Fall Line Hills. It is in this area that streams make the transition from flowing across indurated Paleozoic formations to flowing across unconsolidated cretaceous formations. The topography is a sub-maturely dissected surface.

\section{Previous Investigations}

Several reports that discuss the geology and ground-water resources for the individual counties within the study area have been published. These reports include results of geologic mapping, well inventories, and water-level measurements. They are a valuable source of basic data and are listed, by county, below:

$\begin{array}{lll}\text { Colbert } & -- & \text { Harris and others, } 1963 \\ \text { Franklin -- } & \text { Peace, 1963 } \\ & \text { Peace, 1964 } \\ \text { Lauderdale -- } & \text { Harris and others, 1963 } \\ \text { Lawrence -- } & \text { Harris and McMasters, 1965 } \\ \text { Limestone -- } & \text { McMaster, 1960 } \\ & \text { McMaster, 1963 } \\ \text { Madison } & \text { McMaster and Harris, 1963 } \\ \text { Morgan } & \text {-- } & \text { Christensen and others, } 1975\end{array}$

Additional reports that address specific geographic areas within the study area describe subsurface solutional features (Jones and Varnedoe, 1968) and portray geologic and hydrologic information in an atlas format (Moser and Hyde, 1974; Doyle and others, 1975).

The majority of the study area, especially Limestone and Madison Counties, have been the site of numerous studies conducted to develop a fundamental understanding of karst processes. These studies have provided insight to the complex nature of ground-water movement in the area. LaMoreaux and Powell (1963) presented examples of the complex nature of ground-water movement within the karst terrane, and suggested several stratigraphic and structural controls for ground-water movement in the Huntsville-Madison county area. 
The techniques and concepts introduced in their report were used in test drilling projects conducted throughout the area, but primarily in the Huntsville-Madison County area. Summaries of the test drilling in the study area were published and are listed in the selected references of this report. The reports included a limited amount of interpretive material. Additional studies that described geologic (Snoderegger and Kelly, 1970), geophysical (Joiner and Scarbrough, 1969), and photogeologic (Snoderegger, 1970) techniques were conducted by the Geological Survey of Alabama.

\section{GEOLOGY}

The study area is underlain by rocks of Paleozoic and Mesozoic age that dip gently to the south, southwest, and west. Cambrian and Lower Ordovician rocks occur in the area; however, they do not crop out and are not pertinent to this report. The paleozoic rocks that crop out in the area are in the Ordovician, Silurian, Devonian, Mississippian, and Pennsylvanian Systems. The only Mesozoic rocks in the area are those of the cretaceous system (fig. 3 ).

\section{Structure}

Geologic units in the study area have not been directly subjected to catastrophic tectonic forces; however, their attitude does reflect the presence of a widely-known regional structure, the Nashville dome (fig. 1). The Nashville dome is a domal structure that is roughly centered around Nashville. Because the dome is structurally high, older geologic units are exposed near its center and younger units dip away from it. Consequently, paleozoic units in the study area dip to the south and southwest. The dip in the study area due to this regional feature is about 20 feet per mile (Sonderegger and Kelly, 1970). Cretaceous units are younger than the Nashville dome and, although their attitude is not directly influenced by the dome, they also dip gently to the south and southwest at about 30 feet per mile.

Several prominent linear features are present on the surface of the study area. These features often indicate the presence of vertical fracture zones which are significant to the hydrology of the area. These features are generally considered to be related to relief of stresses (Wyrick and Borchers, 1981). In the Cumberland Plateau section these may be unusually straight valleys or stream reaches. Linear features are not as obvious in the Highland Rim section due to the presence of a consistent thick mantle of residual material. Excellent documentation of the presence of linear features is manifested in cave geometry. The prominent linear nature of solutionally developed caves in the Madison County area is documented by Jones and Varnedoe (1968).

\section{Stratigraphy and Lithology}

The stratigraphy and lithology of the area are dominated by a Mississippian carbonate sequence which crops out over much of the area. The lithology of the carbonate rocks is directly related to many unique hydrologic 
features such as caves, sinkholes, and large springs which occur in the area. Ordovician, Silurian, Devonian, Pennsylvanian, and Cretaceous formations also crop out in the area but are not as prominent as the Mississippian formations.

\section{Ordovician, Silurian, and Devonian Systems}

Relatively thin units of Ordovician, Silurian, and Devonian rocks crop out along the northern boundary of the area, especially in the Elk River valley. These rocks dip gently to the south.

Rocks of Ordovician and Silurian age, represented by the Sequatchie Formation and the Brassfield Limestone, respectively, rarely crop out in the study area. They are generally thin fossiliferous limestones. Rocks of Devonian age represented by the Chattanooga shale are overlain by the Mississippian Fort Payne Chert. The Chattanooga Shale is generally characterized as a dark gray to black thinly bedded shale with occasional sandstone at the base. It is typically about 10 feet thick but may be as thick as 40 feet. Although thin, it is an easily recognized stratigraphic unit that occurs in several southeastern states.

\section{Mississippian System}

The Mississippian System includes several formations that crop out in the study area: They are, from oldest to youngest: Fort Payne Chert, Tuscumbia Limestone, Monteagle Limestone, Pride Mountain Formation, Hartselle Sandstone, Bangor Limestone, Parkwood Formation, and Pennington Formation. These formations are primarily carbonate rocks; however, some are silicate based clastic rocks. These clastic formations which crop out principally in the eastern, western, and southwestern parts consist chiefly of shale, sandstone, clay, and mudstone. They are: Pride Mountain Formation, Hartselle Sandstone, Parkwood Formation, and Pennington Formation. They represent silicate based clastic facies that grade laterally, towards the center of the area, into carbonate units. The Parkwood and Pennington Formations are not included in figure 3 because their outcrops are too small. Figure 4 is a schematic diagram showing stratigraphic relations; however, the reader is referred to Thomas (1972) for detailed stratigraphic information. The carbonate units are discussed individually, from oldest to youngest.

\section{Fort Payne Chert}

The Fort payne chert crops out over much of the study area north of Little Mountain and is overlain by the Tuscumbia Limestone. The Fort Payne Chert is mapped with the Tuscumbia and Monteagle Limestones on the geologic map (fig. 3). The unit is a dark gray siliceous limestone with abundant, occasionally as much as 50 percent, beds of dark gray nodular chert. Coarse bioclastic lithology occurs locally but is generally restricted to lenses. A consistent deposit of residual weathered material, referred to as regolith, mantles the surface of the Fort Payne. The regolith may be as much as 100 


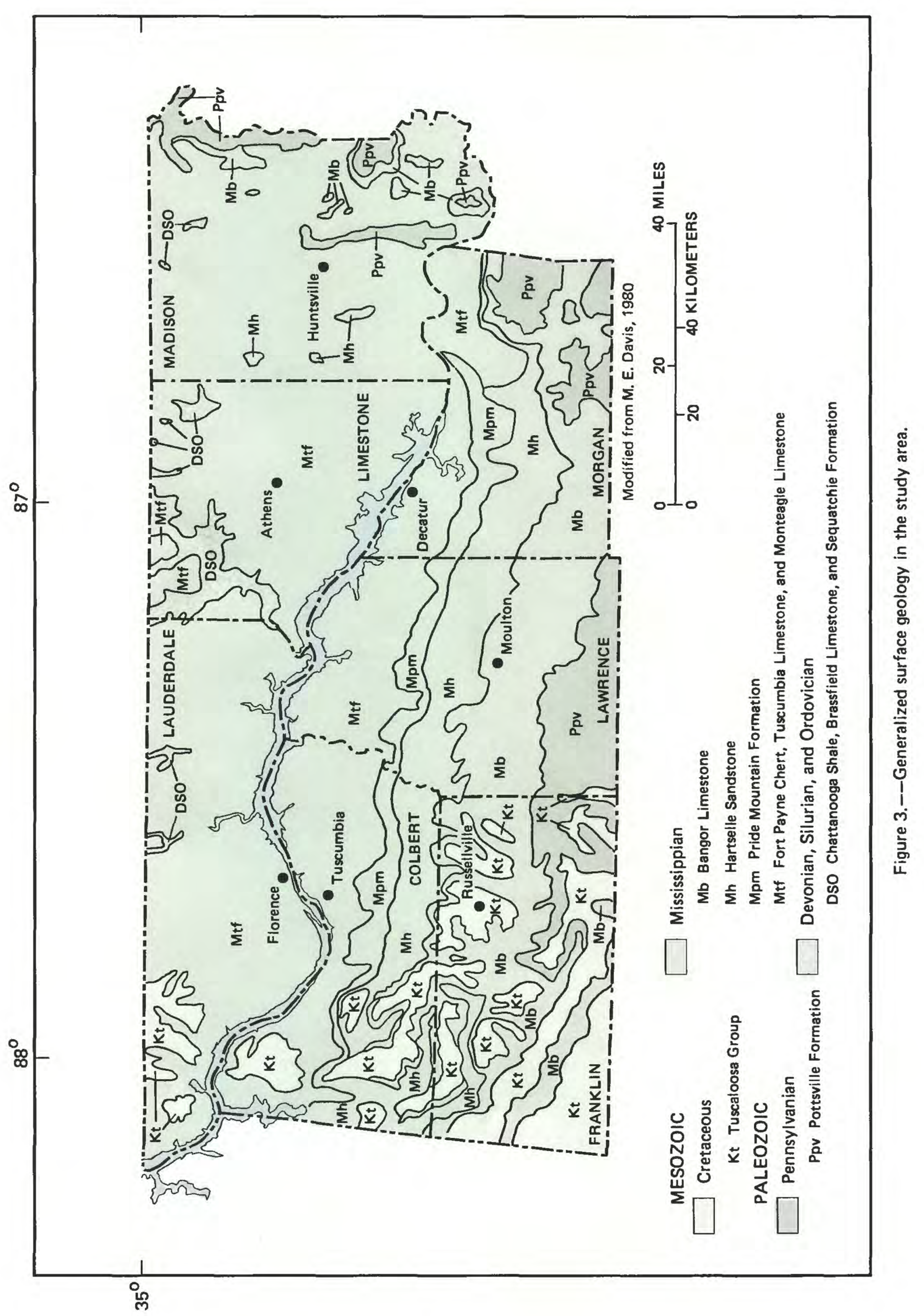




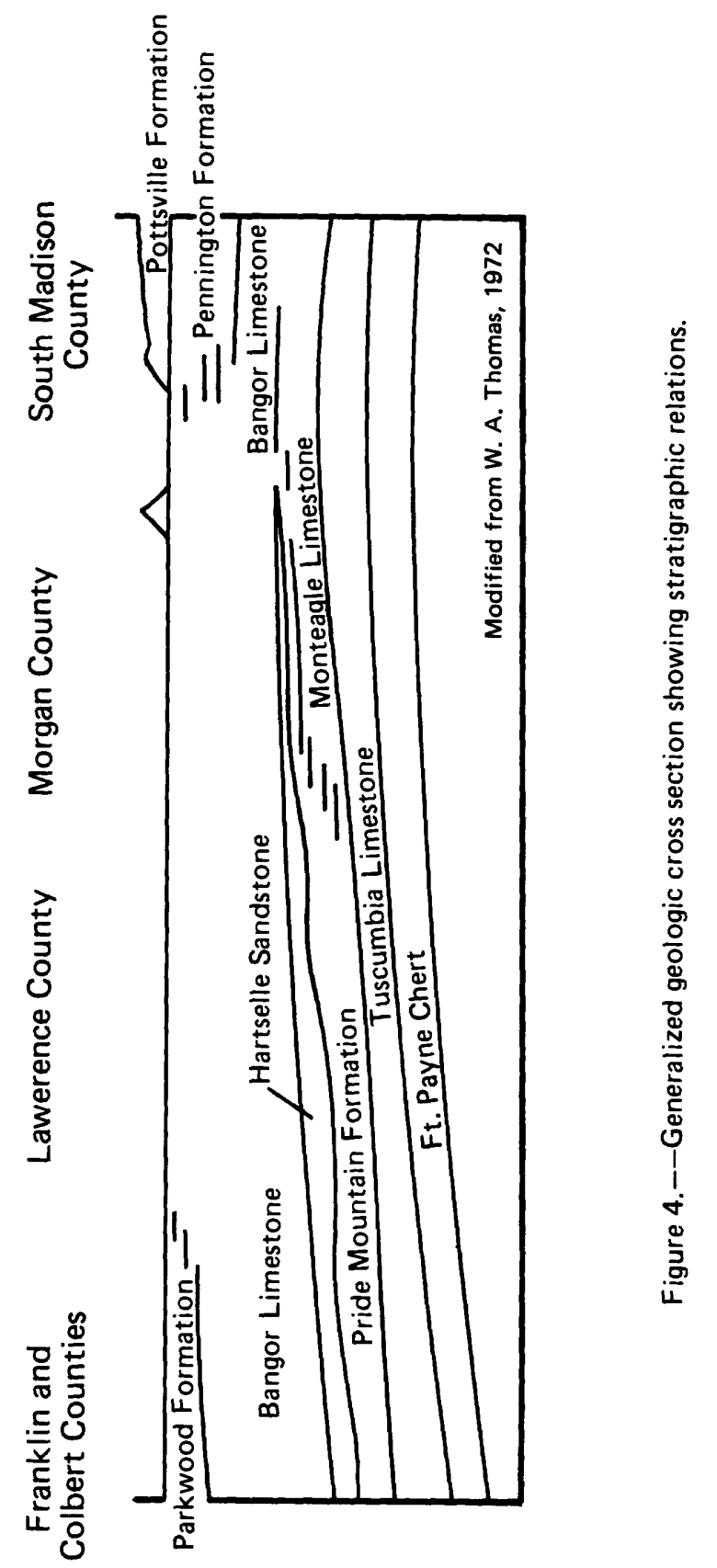


feet thick and is mostly clay; however, it may, especially near bedrock, contain significant layers of chert rubble. Many solutional features are present in the Fort Payne.

\section{Tuscumbia Limestone}

The Tuscumbia Limestone crops out over much of the study area north of Little Mountain in the Highland Rim section. The Tuscumbia consists principally of bedded bioclastic limestone with abundant chert nodules and, in places, beds of light gray chert. Limestone beds are locally as much as 10 or more feet thick but are typically about 1 foot thick. Massive cross-bedded zones of very coarse bioclastic limestones occur locally. The formation thickness is about 200 feet. Regolith on the Tuscumbia is similar to that of the Fort Payne but is generally less cherty. Many solutional features are present in the Tuscumbia and weathered exposures commonly show signs of vertically controlled solution.

\section{Monteagle Limestone}

The Monteagle Limestone crops out along the eastern boundary in the Cumberland Plateau section and its outliers, and also in a relatively extensive area in the southeastern portion of the study area. It is overlain by the Hartselle Sandstone and the Bangor Limestone, and grades laterally to the southwest into the pride Mountain Formation. The lithology and general character of the Monteagle is very similar to the Bangor Limestone, described below. The formation thickness is about 200 feet.

\section{Bangor Limestone}

The Bangor Limestone crops out in the eastern part of the study area and in a broad east-west band south of Little Mountain. It is overlain by the Pottsville Formation and grades laterally to the east into the Pennington Formation and to the southwest into the Parkwood Formation. The lithology of the Bangor consists principally of bioclastic and oolitic limestone with minor amounts of clay and dolomitic limestone. The distribution of these lithologies has been described in detail by Thomas (1972). The formation thickness varies from 350 to 500 feet and thickens, somewhat, to the west. South of Little Mountain, where the formation crops out in the generally flat Highland Rim section, regolith that is usually less than 20 feet thick mantles its surface. Many significant solutional features occur in the Bangor where it crops out in the Cumberland Plateau section.

\section{Pennsylvanian System}

Rocks of Pennsylvanian age represented by the Pottsville Formation crop out in the eastern and southern parts of the study area. The rocks consist principally of quartzose sandstone, shale, conglomerate, and minor amounts of 
coal. These units are tightly cemented with ferruginous and calcite cements. They may be up to 300 feet thick and commonly have bedding plane fractures and vertical joints.

\section{Cretaceous System}

Rocks of Cretaceous age, represented by the coker Formation of the Tuscaloosa Group, crop out in the western and southwestern parts of the study area (fig. 3). They consist of unconsolidated sand, gravel, and clay, dip gently to the west and southwest, and are as much as 170 feet thick. The contact between the Tuscaloosa Group and the underlying units of Paleozoic age represents a major disconformity.

\section{HYDROLOGY}

The source of water in the study area is precipitation which averages about 52 inches annually (U.S. Department of Commerce, 1984b). The amount of precipitation transported out of the area through streamflow, referred to as runoff, is about 22 inches per year. Most remaining precipitation is returned to the atmosphere by evapotranspiration processes. A significant amount of the annual runoff occurs in direct response to precipitation during storms. The actual amount of direct runoff in the study area has not been determined; however, it has been estimated to be about 10 inches for the Tennessee valley as a whole. This amount is probably representative for many streams in the study area (zurawski, 1978). The remaining runoff is discharged to streams from aquifers and will be referred to as baseflow.

A very significant hydrologic characteristic of the study area is the relatively high baseflow. Bingham (1982) reported that recession indexes for streams in the study area, which are directly related to transmissivity and storage characteristics of aquifers, are as much as three or more times the recession indexes for other areas of Paleozoic bedrock in Alabama.

Actual runoff rates for indigenous streams in the study area range from about 20 to 30 inches. These differences can be related to geologic and physical features that affect the amount of water that infiltrates and percolates through surficial deposits to recharge aquifers.

In areas dominated by the pottsville Formation where bedrock is indurated and tightly cemented, soils are relatively thin and slopes are relatively steep. These areas shed more water and have higher runoff rates and lower baseflow than areas dominated by Mississippian carbonate rocks which are indurated but have thick residual mantles and solutional features, and crop out extensively in gentle sloping areas. Most precipitation in pottsville areas runs off directly and has little opportunity to recharge aquifers; consequently, baseflow for streams draining pottsville areas, such as the basin upstream from paint Rock River, is low. Not as much precipitation runs off directly during storms in areas of Mississippian carbonate rocks. However, much of the precipitation which does not run of $f$ directly recharges aquifers and is discharged to streams such as the basin upstream from flint River as relatively high baseflow (table 1 ). (See figure 5.) 
DISCHARGE, IN CUBIC FEET PER SECOND PER SOUARE MILE

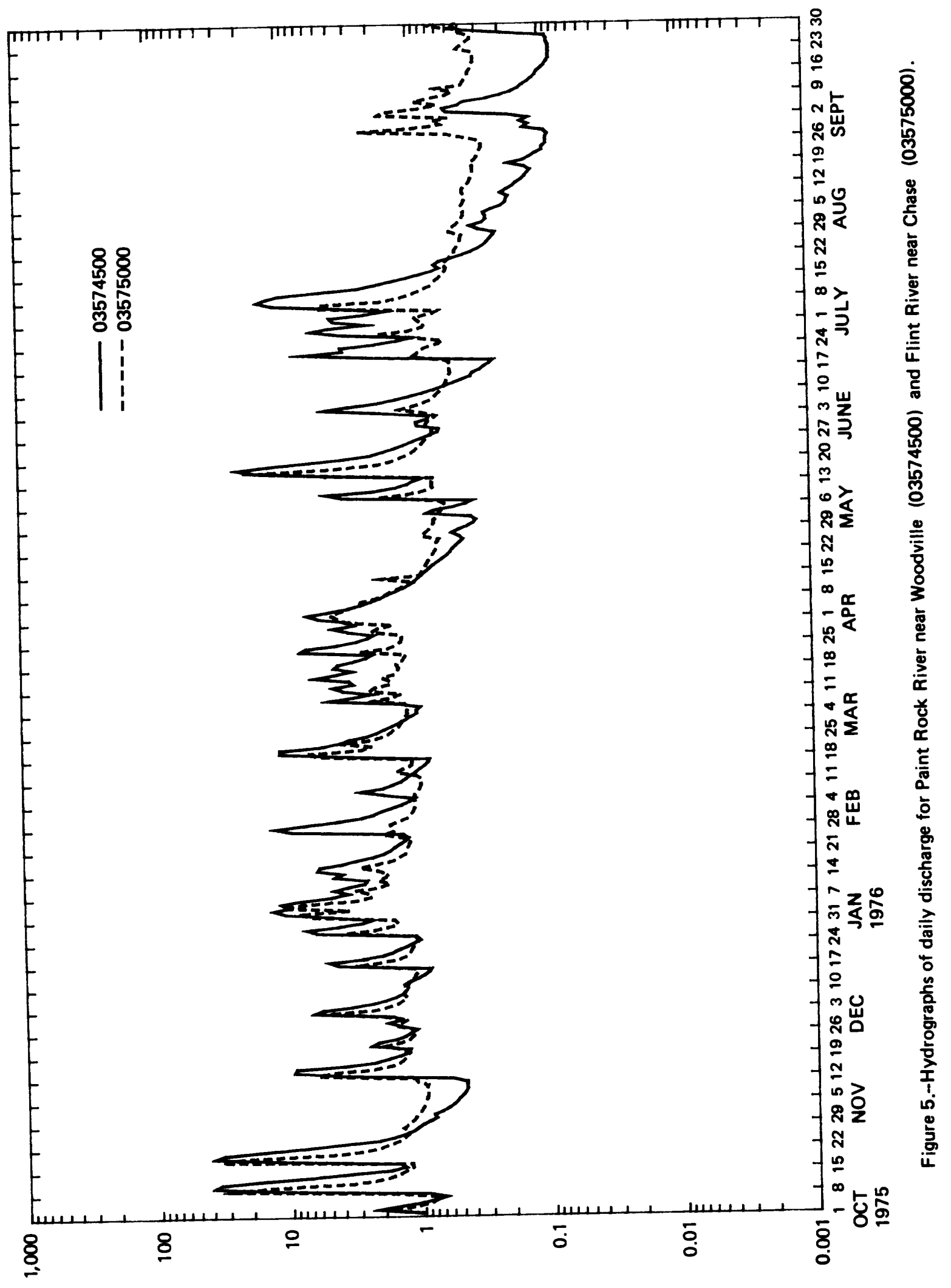


Ground water in the study area is influenced more greatly than surface water by geology due, principally, to lithologic characteristics that affect the water-bearing characteristics of formations.

The Mississippian carbonate rocks are indurated and thoroughly cemented; consequently they have very little inter-granular space. Their porosity and permeability are related to stress-relief (vertical) and bedding-plane (horizontal) fractures. This type of porosity and permeability is referred to as secondary because it was developed after formation of the rock; it is typically non-uniform and can vary significantly over short distances. The secondary features of the carbonate aquifers are also significantly affected by their chemical composition. The principal constituent of the Mississippian carbonate rocks is calcium carbonate $\left(\mathrm{CaCO}_{3}\right)$, a compound which is readily soluble by several dilute acids that are normally present in precipitation, runoff, and percolating ground water. Solutional processes have enlarged relatively small and insignificant fractures into very significant cavernous features in many places in the study area. The specific chemical mechanisms of these processes are comprehensively described by Krauskopf (1967), and their importance with respect to solutional development of secondary porosity is described by stringfield and others (1974).

The indurated and tightly-cemented rocks of the pottsville Formation have very little primary porosity or permeability. Their water bearing properties, like those of the carbonates, are related to secondary porosity and permeability. The siliceous nature of these rocks does not permit significant solutional enhancement of secondary features.

The unconsolidated sediments of the Tuscaloosa Group are relatively wellsorted. Consequently, they have inter-granular space which provides relatively uniform porosity and permeability. This type of porosity and permeability is referred to as primary because it is inherent. The amount of water that these sediments may store and transmit is principally related to their thickness and areal extent.

\section{Major Aquifers and Their Water-Bearing Characteristics}

Three major aquifers have been defined for the purposes of this report. They are the Tuscumbia-Fort Payne aquifer, the Bangor aquifer, and the Tuscaloosa aquifer. Quantitative data describing the specific hydraulic characteristics for these aquifers are not available; however, each aquifer is capable of yielding significant amounts of water to wells and is currently supplying municipal users. Data for public-supply wells in the study area are shown in table 2, and the well locations are shown on plate 1 . Ordovician formations and the pottsville Formation yield only small amounts of water and are not designated as major aquifers because they are not used for municipal supply within the area. The Pottsville Formation is a major aquifer in other parts of the state. Although significant quantities of water may be available from gravel lenses in the regolith, it also has not been designated as a major aquifer. This is due to the preference of regulatory authorities and users to obtain water from bedrock aquifers. 
The Tuscumbia-Fort Payne aquifer includes the Monteagle Limestone, Tuscumbia Limestone, and Fort Payne Chert. The aquifer name emphasizes the prominence of the Tuscumbia Limestone and the Fort payne Chert which are the most significant sources of water within it. The Monteagle Limestone is a significant source of water in only the southeastern part of the study area. The Tuscumbia-Fort Payne aquifer is the major aquifer for all of the study area north of Little Mountain and is used for public supplies throughout its outcrop area. The aquifer underlies the entire study area, but has not been developed south of Little Mountain because of the availability of water from the overlying Bangor aquifer. The aquifer is recharged throughout its outcrop by water which infiltrates and percolates through the regolith. The base of the aquifer is the contact with the underlying Chattanooga Shale.

Water in the Tuscumbia-Fort Payne aquifer is partially confined because of the lower hydraulic conductivity of the overlying residual mantle. The Tuscumbia-Fort payne aquifer is the most widely-used aquifer for public supply in the study area (table 2). Cavernous porosity is present many places where dissolution has enlarged joints and bedding-planes. Wells which penetrate these features produce large quantities of water. The williams well (57), for instance, is routinely pumped at rates greater than $3,200 \mathrm{gal} / \mathrm{min}$.

\section{Bangor Aquifer}

The Bangor aquifer includes the Bangor Limestone and the underlying Hartselle Sandstone. Its thickness and outcrop area is essentially the same as that described for the Bangor Limestone in the geology section although minor differences occur in the vicinity of the Little Mountain. The Hartselle Sandstone is a significant source of water in only a small part of the study area.

The aquifer is recharged throughout its outcrop area by water which infiltrates and percolates through the regolith. The area of use for water supplies is generally restricted to its outcrop area. The base of the aquifer is the contact with underlying formations (Pride Mountain Formation or Monteagle Limestone).

Water in the Bangor aquifer, like the that in the Tuscumbia-Fort Payne aquifer, typically is partially confined. Solutionally enlarged fractures in the Bangor Limestone may be significant sources of water but, the aquifer is not, used extensively in the study area.

\section{Tuscaloosa Aqui fer}

The Tuscaloosa aquifer is in the Tuscaloosa Group in the study area. Its thickness and outcrop area conforms to the description of the Tuscaloosa Group in the Cretaceous System presented in the geology section. The aquifer is not overlain by any other formation in the study area and its outcrop is also its 
recharge area. The base of the Tuscaloosa aquifer is the contact with underlying formations (Bangor Limestone or Pottsville Formation). Springs commonly occur at the contact between the Tuscaloosa aquifer and the pottsville Formation where the rocks crop out.

Water in the Tuscaloosa aquifer generally occurs under water-table conditions due to the lack of a widespread effective confining layer; however, confined conditions locally occur due to differences in hydraulic conductivities of units within the aquifer. The aquifer may yield up to $350 \mathrm{gal} / \mathrm{min}$ to properly constructed wells (Peace, 1964). Most wells, however, produce significantly less; the average for public supply wells in the study area is $160 \mathrm{gal} / \mathrm{min}$. Many municipalities that formerly used the Tuscaloosa aquifer for water supply currently use surface-water, but the aquifer is still used by several small communities, principally in the southwestern part of the study area.

\section{Potentiometric Surfaces for Major Aquifers}

Contour lines are used to display the configuration of the potentionetric surface for a particular aquifer. They are constructed by contouring measured water levels or heads relative to a datum, usually sea level. Maps which show the potentiometric surface provide several types of information; however, they are most commonly used to determine the direction of ground-water movement. The direction of ground-water movement is perpendicular to potentiometric contours or down the hydraulic gradient.

Plate 1 shows the potentiometric surfaces for the three major aquifers in the study area; it also shows the locations of public supply wells. The contours are from the previously published reports listed in table 3 . The data base represents information collected principally during the period of 1955-63 at approximately 2,000 wells. Because of the scale of the map $(1: 250,000)$ and the contour interval (50 feet) only general trends for the potentiometric surfaces are shown.

The potentiometric contours for the Tuscumbia-Fort Payne aquifer show ground-water movement toward the Tennessee River from the north and south. Minor variations shown at this scale are generally related to topography. The trend is for ground water to move from higher to lower topographic areas.

The potentiometric contours for the Bangor aquifer show ground-water movement is generally to the south, away from Little Mountain. This slope conforms to altitudes for the land surface in the area and reinforces the concept that ground water generally moves from higher to lower topographic areas.

The potentiometric contours for the Tuscaloosa aquifer show ground-water movement in Franklin County is to the west toward the Tombigbee River. In Colbert and Lauderdale Counties, the contours for the Tuscaloosa merge with those for the Tuscumbia-Fort Payne aquifer, suggesting that the two aquifers are inter-connected in this area. 
Factors Affecting Ground-Water Movement and Occurrence

The movement and occurrence of ground water in the Tuscaloosa aquifer is markedly different from movement in the Tuscumbia-Fort Payne and Bangor aquifers. This is principally due to the presence of significant secondary porosity and permeability that has been developed through solutional enlargement of fractures or systems of fractures in the carbonate aquifers. The magnitude of difference in movement and occurrence of ground water in these aquifers is increased due to relict structure in the regolith as well as the surface and basal configuration of the carbonate aquifers.

Ground water in the carbonate aquifers occurs mostly in secondary porosity. Solutionally enlarged fractures can yield substantial quantities of water. However, not all systems of solutional development are sources of ground water. Substantial solutional fracture systems that are essentially devoid of ground water, such as the Natural Well system on Monte Sano near Huntsville (Jones and Varnedoe, 1968), exist in the study area. These systems probably represent secondary features developed when regional base level was higher than its present location. In order for solutionally developed systems to be significant with respect to water supply, they must be developed in a saturated zone which is associated with the base level of nearby streams. Additional factors which affect the occurrence of ground water in the carbonate aquifers include the basal and surface configuration of the aquifers and the thickness and character of regolith.

Ground-water movement in the carbonate aquifers is markedly preferential with respect to direction due to their non-uniform permeability. Such aquifers are referred to as anisotropic. Ground-water movement in anisotropic aquifers is affected principally by gravity but also by the geometry of the confining fracture system. Cavernous features have been formed by solution processes in fractures and fracture systems at many places in the carbonate aquifers. If sufficient hydraulic gradient is present water can move quite rapidly through these fractures or systems of fractures.

A substantial amount of information concerning the configuration of the Chattanooga shale, the base of the Tuscumbia-Fort Payne aquifer, has been collected in Limestone and Madison Counties. These data indicate that there are depressions on the surface of the Chattanooga Shale. Areas of depressions provide a reservoir-like area that is well suited for ground-water storage. In Madison County these depressions may be as much as 40 feet deep and their areal extent may be several square miles (Doyle and others, 1975). These depressions, in conjunction with solutional development of fractures in the overlying carbonate rocks, can be significant sources of ground water. A test well in Madison County, MT-205 (Bossong, 1978), developed at such a site was pumped at a rate of $500 \mathrm{gal} / \mathrm{min}$ for approximately 72 hours with 7.88 feet of drawdown.

Depressions on the surface of the carbonate bedrock, shown for Madison County on maps of regolith thickness (Doyle, 1975), may have the same effect on ground-water availability as depressions on the surface of the Chattanooga Shale. Chert rubble at the base of the regolith may also be thicker in these depressions. The Lowe-Mill well (table 2) which is routinely pumped at 1,000 $\mathrm{gal} / \mathrm{min}$ is an example of a public supply in this type of setting. 
A feature of the regolith that has been referred to as relict structure is an additional factor that affects the availability of water at the LoweMill site and others like it. As the regolith is formed by weathering forces, the soluble limestone matrix is dissolved much more rapidly than the less soluble chert inclusions. The residual layers of chert rubble, or relict structures, are remarkably similar to gravel beds. They represent areas of high porosity and permeability that are capable of efficiently transmitting water through the regolith.

The uniform nature, or homogeneity, of the Tuscaloosa aquifer allows water within it to be equally free to move in any direction. Such an aquifer is referred to as isotropic. Ground-water movement within an isotropic aquifer is principally affected by gravity but also by local lithologic variations, which in this case are minor, and by the contact of the aquifer with underlying formations such as the pottsville which are significantly less porous and permeable. Water in the aquifer moves along the hydraulic gradient (plate 1) which generally parallels the westerly-sloping land surface.

Ground water in the Tuscaloosa aquifer occurs in inter-granular space which is relatively uniform throughout. The amounts of water available are related to factors such as the thickness and areal extent of the aquifer. A well penetrating a thin outlier of the aquifer, for instance, will produce much less water than a well penetrating a thick areally extensive portion of the aquifer.

\section{POTENTIAL FOR AQUIFER CONTAMINATION}

The potential for aquifer contamination exists in any aquifer wherever recharge processes are active. The sources of contamination may be point sources, such as leaking waste ponds, or non-point sources such as heavilytreated agricultural areas. Areas which have potential for surface contamination can be discussed and generally categorized into areas that are susceptible, highly susceptible, and extremely susceptible. Some general comments concerning the fate of any contaminants that enter the ground-water system can also be made.

The major aquifers in the study area are recharged throughout their outcrop and any contaminants present in the recharge area of an aquifer can reasonably be expected to enter that aquifer. Consequently, the major aquifers are susceptible to contamination throughout their entire outcrop area.

Certain topographic settings which are highly susceptible to contamination from the surface can be generally described. Surfaces which are above the potentiometric surface and are poorly drained represent areas where surface runoff is inhibited and recharge may become more active. Examples of this type of setting in the study area include closed contour depressions, extensive areas of poor drainage, and perched swamps. These features occur commonly; however, it is beyond the scope of this report to delineate these areas. Their presence can be determined through field inspection, use of the potentiometric contours on Plate 1, and 7.5 minute topographic maps. 
Areas that are extremely susceptible to surface contamination are those in which solutional processes have been active. Most obviously they include features such as sinkholes where surface water may enter the ground-water system with little or no filtration. Sinkholes occur commonly throughout the carbonate portions of the study area and have been mapped at a scale of one inch equals 2 miles on a county by county basis (U.S. Geological survey, 1977b). The reader is referred to these county maps for locations of known sinkholes, as the scale on plate 1 cannot accommodate the numerous individual sinkholes that have occurred in the area. Plate 1 does, however, show areas of known sinkholes that have dimensions greater than 0.2 miles. Additional information concerning locations of sinkholes can be obtained from 7.5 minute topographic maps which delineate historical sinkholes.

Additional areas that are extremely susceptible to surface contamination include areas of closed contour depressions that do not expose bedrock and swallets or openings in stream beds where surface drainage may enter the ground-water system. Closed contour depressions typically indicate the presence of solution features on the underlying bedrock surface. They occur throughout the study area and can be located on 7.5 minute topographic maps or during field inspection on a site specific level. These depressions commonly contain ponded surface water for a period of days or weeks after rains. Areas where available records indicate that streams discharge directly to the subsurface are indicated on plate 1 .

It is important to determine recharge areas when dealing with aquifer protection; however, it is also important to have some knowledge concerning the relation of recharge areas to specific supply systems. It is desirable, for instance, to be able to delineate and protect the aquifer area that delivers water to pumping wells. Normally, in isotropic homogenous aquifers, water produced from a pumping well is derived locally. However, the highly anisotropic and cavernous features of the carbonate aquifers are capable of transmitting water to pumping wells from outside the local area.

\section{Need for Additional Studies}

Many of the hydrogeologic processes which occur in the carbonate aquifers are not completely understood. Additional studies which investigate these processes should be encouraged. It is likely that a comprehensive analysis of existing water-quality and physiographic data would result in a significant contribution to the current understanding of these processes.

Site specific data, while not as well suited for developing general knowledge, can be used to define characteristics for specific supply systems. For instance, the area directly affected by withdrawals from a highlyaniosotropic aquifer such as the carbonate aquifers in the study area is controlled by the geometry of the aniosotropic features, and information that defines this geometry is extremely valuable with respect to protecting the system. A few of the many techniques to determine geometry information are briefly described below. 
The area directly affected by withdrawals from an isotropic aquifer can usually be determined through analysis of carefully-designed and executed aquifer tests. The mathematical assumptions required for this type of aquifer test analysis, however, are not valid in the highly anisotropic and cavernous carbonate aquifers. Test drilling is generally an unsatisfactory method of obtaining this information due to the relatively large expenditures required. Geophysical methods are often employed but generally do not provide the resolution necessary to delineate geometry of the systems. Geophysical techniques can, however, be reasonably successful with respect to delineating the configuration of the aquifer surface and may be useful for ground-water prospecting. Dyes and (or) dissolved constituents which can be introduced into the system and detected at low concentrations have been used successfully to trace ground-water movement and indirectly define the geometry. Another successful technique for delineating fracture systems is the use of remote sensing. Both Newton (1976) and Sonderegger (1970) have demonstrated the effectiveness of these techniques. Newton, in particular, has been successful in identifying and defining features indicative of advanced subsurface solution that can be observed with color and color infra-red photographs taken from the air. They include among others, small scale linear features, vegetal stress or vigor, local drainage modifications, and openings such as sinkholes.

\section{SUMMARY AND CONCLUSIONS}

Three aquifers in a seven county area in north Alabama are used for public supply by municipalities. The Tuscumbia-Fort Payne aquifer includes the Tuscumbia Limestone, and the Fort Payne Chert, and overlying Monteagle Limestone present only in the southeastern part of the study area. The aquifer occurs principally in the northern part of the study area and is a major source of ground water used for public supply. The Bangor aquifer includes the Bangor Limestone and the Hartselle Sandstone. It occurs principally in the southern part of the study area and is capable of supplying large quantities of ground water but currently is not being used extensively. The Tuscumbia-Fort Payne and the Bangor aquifers are principally carbonate aquifers. The Tuscaloosa aquifer includes the Tuscaloosa Group. It occurs principally in the southwestern part of the study area and supplies water to several small systems in that area.

Water in the carbonate aquifers occurs in secondary features related to fractures that have been enlarged, often to cavernous proportions, due to solution processes. These fractures cause water movement within the aquifer to be markedly preferential, or anisotropic. Large quantities of ground-water may be obtained in anisotropic aquifers such as these. The occurrence of ground water in these aquifers is controlled largely by the magnitude of solutional features and the configuration of the surface and bottom of the aquifer. Ground water in the Tuscaloosa aquifer occurs in relatively uniform primary features. Ground-water movement in this aquifer is isotropic and the amounts of water available are principally related to thickness and areal extent of the aquifer. 
All of the major aquifers are recharged throughout their outcrop in the study area and, consequently, they are susceptible to contamination throughout their outcrop. Surface contaminants are most likely to enter the ground-water system in poorly drained areas where the land surface is above the potentiometric surface, areas of extensive solution, and sinkholes. Sinkholes provide the most direct path between surface contamination and the ground-water system.

Recharge to most pumping wells, especially those in the Tuscaloosa aquifer, is probably local. Due to the presence of cavernous features, carbonate aquifers have a potential to be recharged by water which comes from outside what is normally conceived as a local area. The area directly affected by pumpage in an isotropic aquifer can be reasonably well defined through a carefully planned and executed aquifer test. Delineation of the area directly affected by pumping a well in an anisotropic aquifer is normally quite difficult and may require the use of geophysical or remote sensing techniques, or both. 
Bingham, R.H., 1982, Low-flow characteristics of Alabama streams: U.S. Geological Survey Water-Supply Paper 2083, 27 p.

Bossong, C.R., 1978, Hydrologic and geologic data for water management in Huntsville-Madison County, Alabama, water year 1978: Geological survey of Alabama Open File Report, 63 p.

Christensen, R.C., Faust, R.J., and Harris, W.F., 1975, Basic data used in evaluation of environmental geology and hydrology, Huntsville and Madison County, Alabama: U.S. Geological survey open-file report.

Dodson, C.L. and Harris, W.F., 1961, Interim report on the geology and ground-water resources of Morgan County, Alabama: Geological Survey of Alabama Information Series 24,129 p.

- 1965, Geology and ground-water resources of Morgan County, Alabama: Geological survey of Alabama Bulletin 76, $90 \mathrm{p}$.

Doyle, F.L. and others, 1975, Environmental geology and hydrology, Huntsville and Madison County, Alabama: Geological Survey of Alabama Atlas series $8,118 \mathrm{p}$.

Fenneman, N.M., 1938, Physiography of the Eastern United States: New York, MCGraw-Hill Book Company, 714 p.

Harris, H.B., Moore, G.K., and Causey, L.V., 1960, Interim report on groundwater study in Colbert County, Alabama: Geological Survey of Alabama Information Series 20,59 p.

Harris, H.B., Moore, G.K., and West, L.R., 1963, Geology and ground-water resources of Colbert County, Alabama: Geological survey of Alabama County Report 10, $71 \mathrm{p}$.

Harris, H.B., Peace, R.R., and Harris, W.F., 1963, Geology and ground-water resources of Lauderdale County, Alabama: Geological survey of Alabama County Report 8, 178 p.

Harris, W.F., and McMaster, W.M., 1965, Geology and ground-water resources of Lawrence County: Geological Survey of Alabama Bulletin 78, $70 \mathrm{p}$.

Heath, R.C., 1983, Basic ground-water hydrology: U.S. Geological Survey Water-Supply Paper 2220, 84 p.

Johnston, W.D., 1933, Ground water in the Paleozoic rocks of northern Alabama: Geological Survey of Alabama special Report 16, $414 \mathrm{p}$.

Joiner, T.J. and Scarbrough, W.L., 1969, Hydrology of limestone terranes, geophysical investigations: Geological survey of Alabama Bulletin 94D, $43 \mathrm{p}$. 
Jones, W.B. and Varnedoe, W.W., 1968, Caves of Madison County, Alabama: Geological Survey of Alabama Circular 52, $128 \mathrm{p}$.

Krauskopf, K.B., 1967, Introduction to geochemistry: New York, McGraw-Hill Book Company, 721 p.

LaMoreaux, P.E., Swindel, G.W., and Lamphere, C.R., 1950, Ground-water resources of the Huntsville area: Geological Survey of Alabama Bulletin $62,82 \mathrm{p}$.

LaMoreaux, P.E. and Powell, W.J., 1963, Stratigraphic and structural guides to the development of water wells and well fields in a limestone terrane: Geological Survey of Alabama Reprint Series 6, $134 \mathrm{p}$.

Moffett, T.B. and Bossong, C.R., 1981, Hydrologic and geologic data for waterresources management in Madison County, Alabama 1974-78: Geological Survey of Alabama open-file report, $109 \mathrm{p}$.

McMaster, W.M., 1960, Interim report on ground-water studies in the Athens area, Alabama through January 1960: Geological survey of Alabama Information Series $23,72 \mathrm{p}$. 1963, Geology and ground-water resources of the Athens area, Alabama: Geological Survey of Alabama Bulletin $71,45 \mathrm{p}$.

McMaster, W.M. and Harris, W.F., 1963, Geology and ground-water resources of Limestone County, Alabama, a reconnaissance report: Geological survey of Alabma County Report 11, $43 \mathrm{p}$.

Moser, P.H. and Hyde, L.W., 1974, Environmental geology, an aid to growth and development in Lauderdale, Colbert, and Franklin Counties, Alabama: Geological Survey of Alabama Atlas Series 6, 45 p.

Newton, J.G., 1976, Early detection and correction of sinkhole problems in Alabama, with a preliminary evaluation of remote sensing applications: Alabama Highway Department HPR Report $76,83 \mathrm{p}$.

Peace, R.R., 1962, Geology and ground-water resources of the Russellville area, Alabama, an interim report: Geological survey of Alabama Information Series $28,29 \mathrm{p}$.

1963, Geology and ground-water resources of Franklin County, Alabama, a reconnaissance report: Geological Survey of Alabama Bulletin 72,55 p.

1964, Geology and ground-water resources of Russellville area: Alabama: Geological Survey of Alabama Bulletin 77, $83 \mathrm{p}$.

Sanford, T.H., 1959, Interim report on the ground-water resources in the Huntsville area, Alabama, to February 1957: Geological Survey of Alabama Information Series $9,131 \mathrm{p}$. 
Sanford, T. H., 1965, Ground-water conditions in the Huntsville area, Alabama: Geological Survey of Alabama Circular 24, 46 p.

Sonderegger, J.L., 1970, Hydrology of limestone terranes, photogeologic investigations: Geological Survey of Alabama Bulletin 94B, 26 p.

Sonderegger, J.L. and Kelly, J.C., 1970, Hydrology of limestone terranes geologic investigations: Geological Survey of Alabama Bulletin 94C, $146 \mathrm{p}$.

Stringfield, V.T., LaMoreaux, P.E., and LeGrand, H.E., 1974, Karst and paleohydrology of carbonate rock terranes in semiarid and arid regions with a comparison to humid karst of Alabama: Geological survey of Alabama Bulletin 105, 106 p.

Thomas, W.A., 1972, Mississippian stratigraphy of Alabama: Geological Survey of Alabama Monograph 12, 121p.

U.S. Department of Commerce, 1984, Local population estimates: Bureau of Census Series P-26, No. 82-1-SC, $14 \mathrm{p}$.

1984, Local climatological data, annual summary: National Oceanic and Atmospheric Administration, published annually.

U.S. Geological Survey, 1977a, Water resources data for Alabama, 1976: U.S. Geological Survey water-data reports, published annually.

1977b, Areas in which sinkholes have occurred or can occur in colbert, Franklin, Lauderdale, Lawrence, Limestone, Madison, and Morgan Counties, Alabama: U.S. Geological survey unnumbered open-file report, 7 sheets.

Wyrick, G.G. and Borchers, J.W., 1981, Hydrologic effects of stress-relief fracturing in an Appalachian valley: U.S. Geological Survey Water Supply Paper 2177, 51 p.

Zurawski, A., 1978, Summary appraisals of the nation's ground-water resources --Tennessee region: U.S. Geological survey Professional Paper 813-L, 35 p. 
Table 1.--streamflow characteristics for selected stations

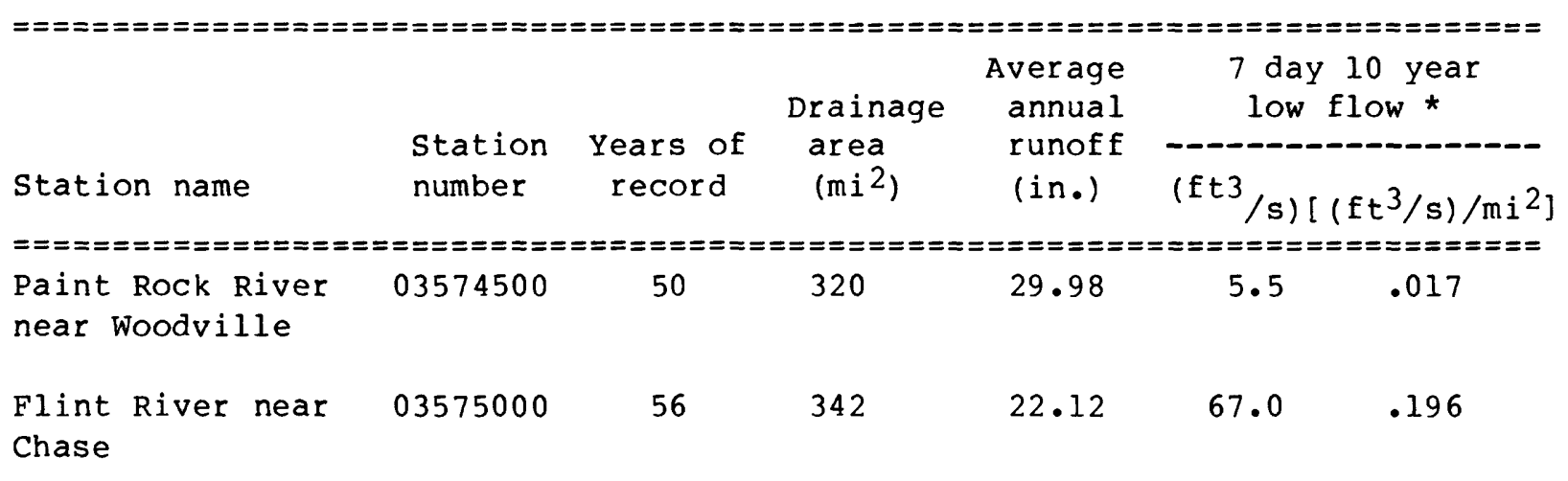

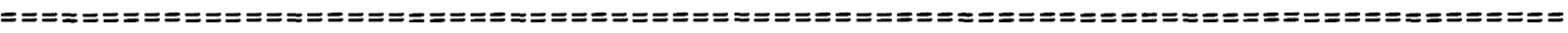

* Computed from station records 


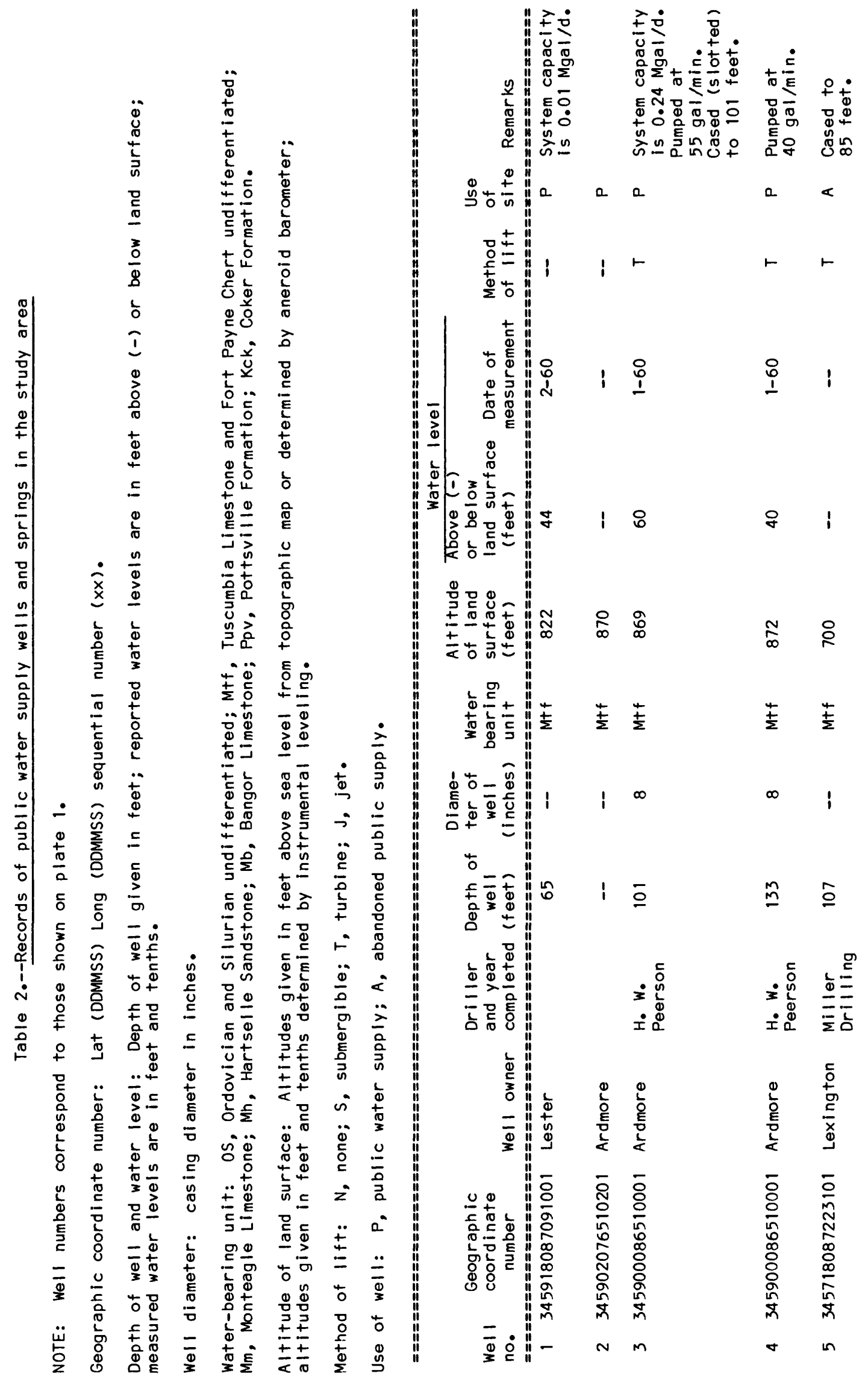




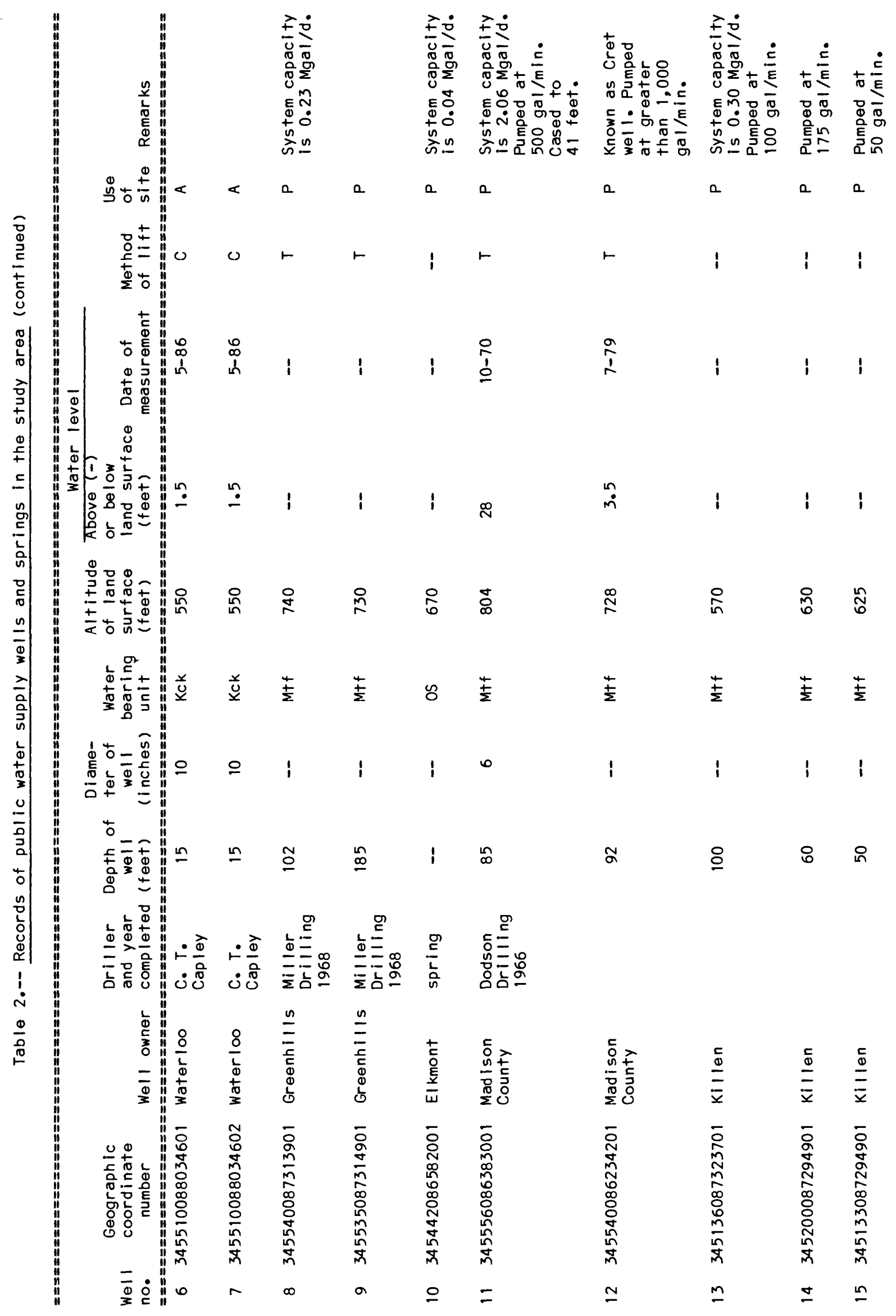




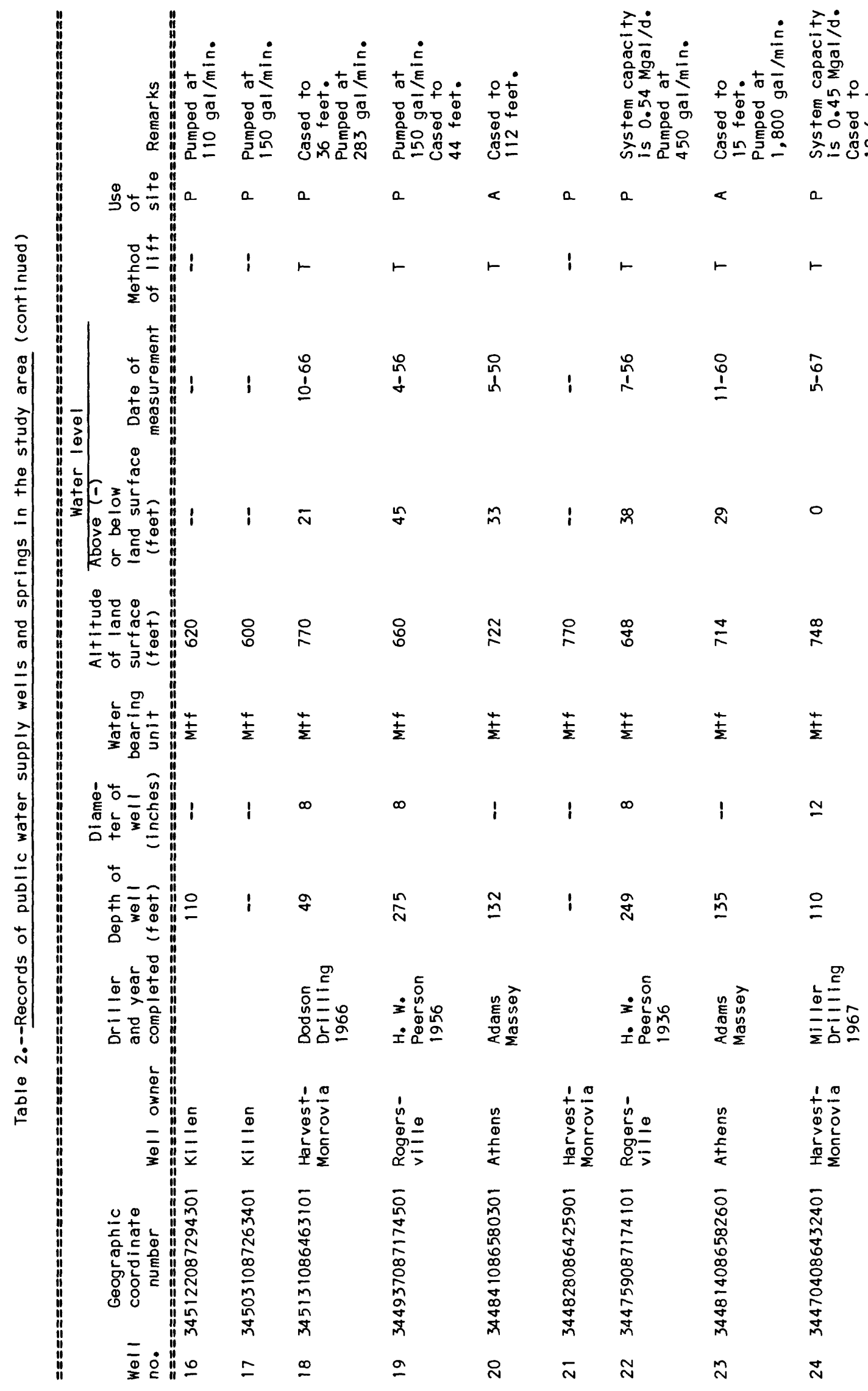




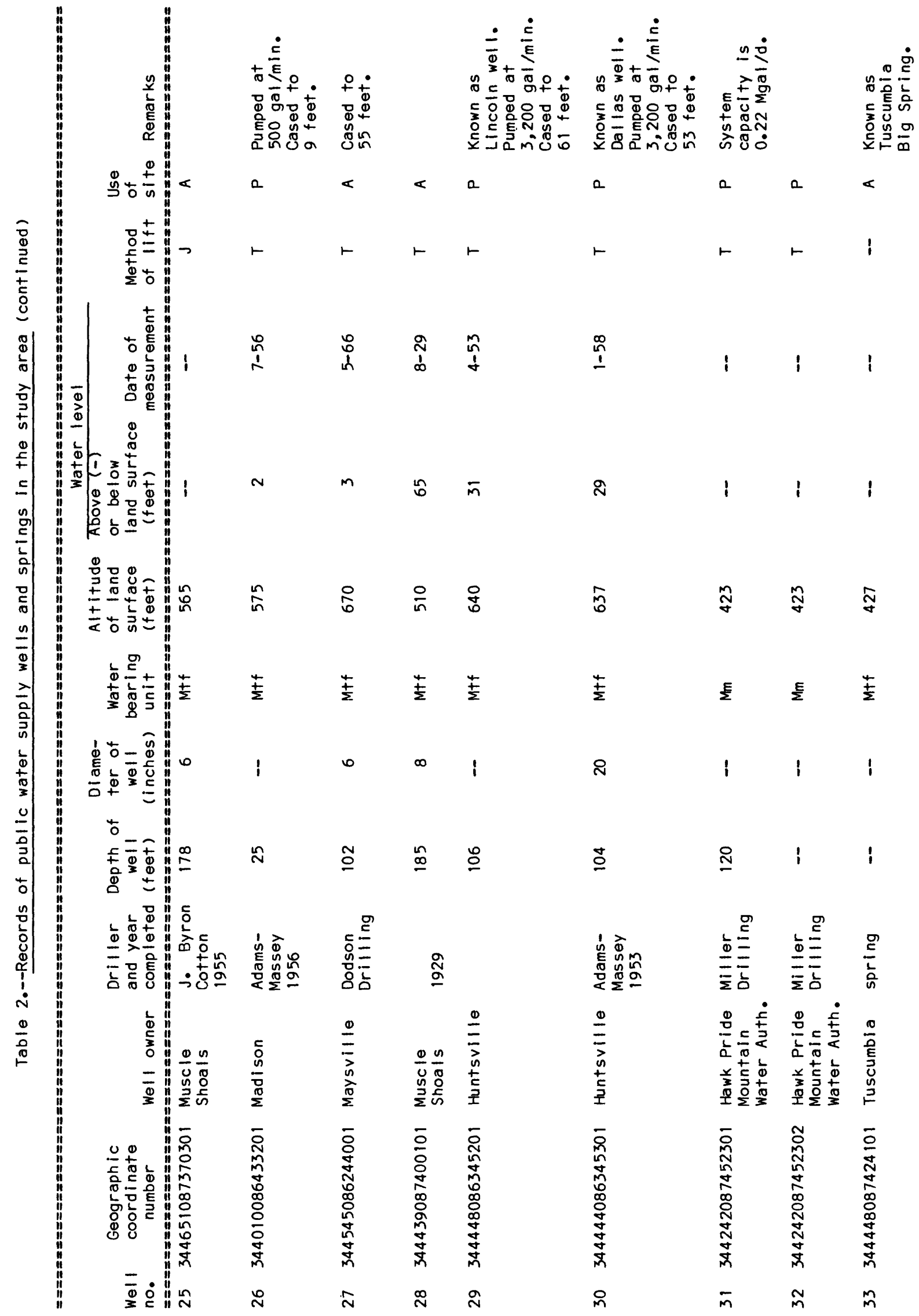




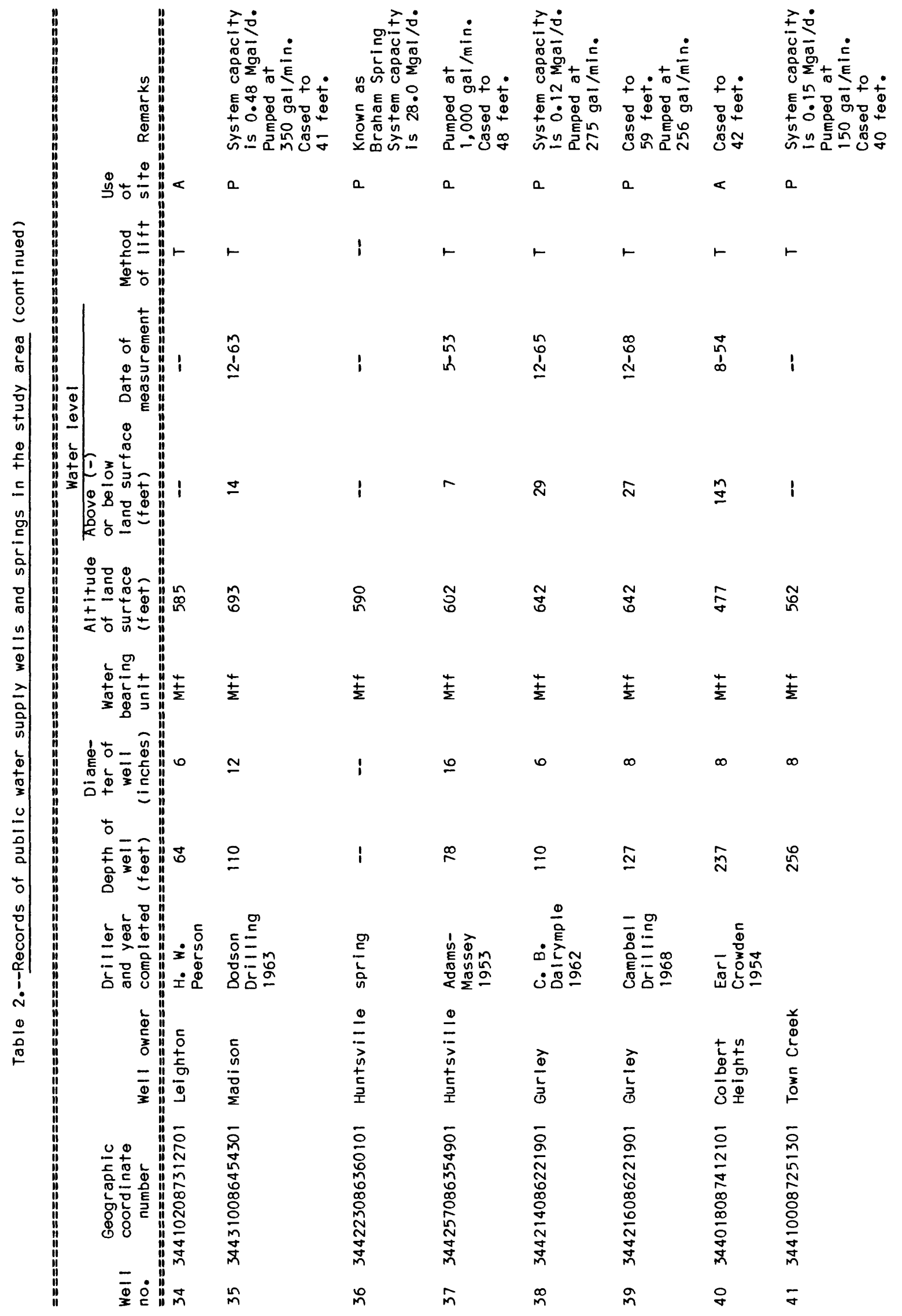




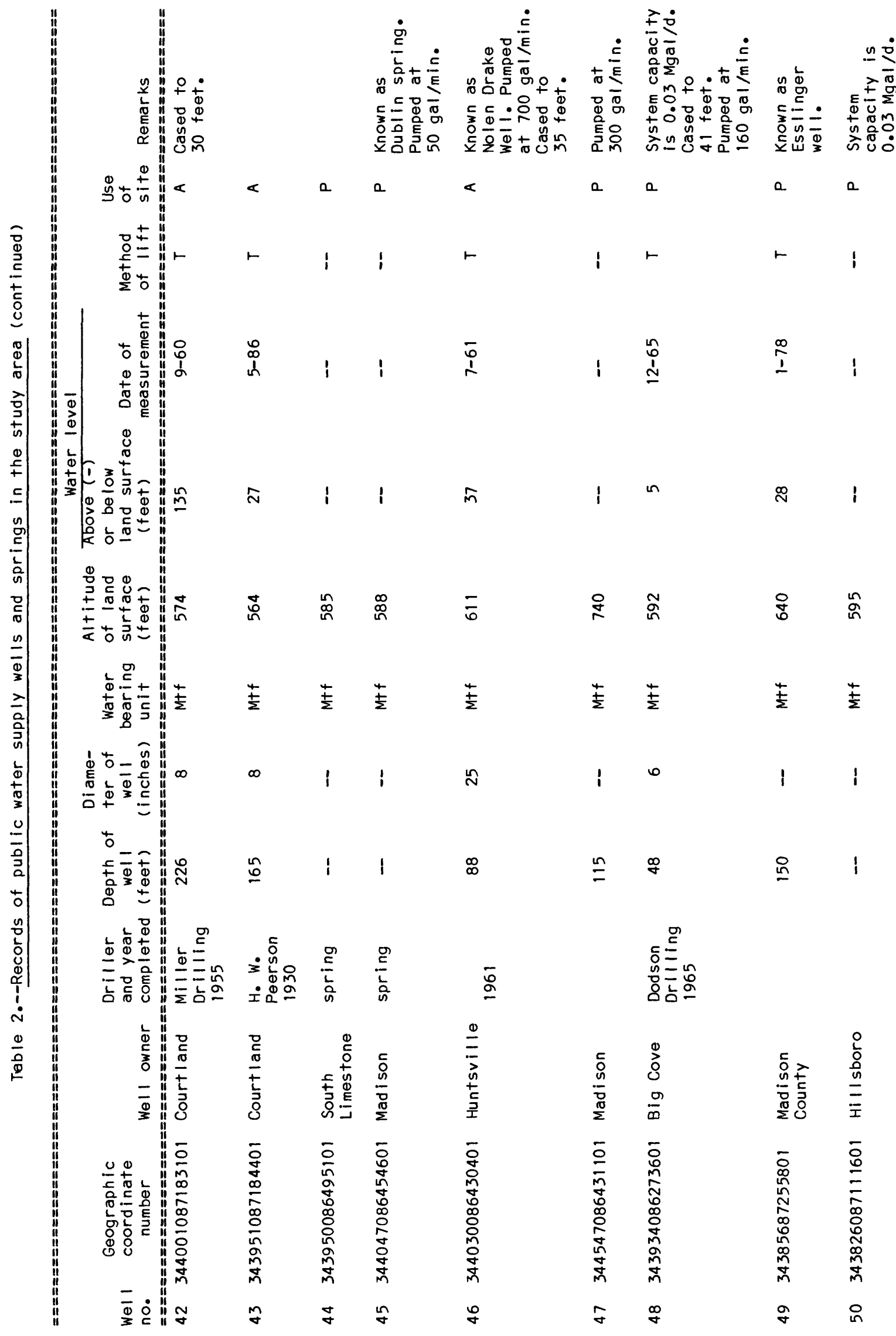




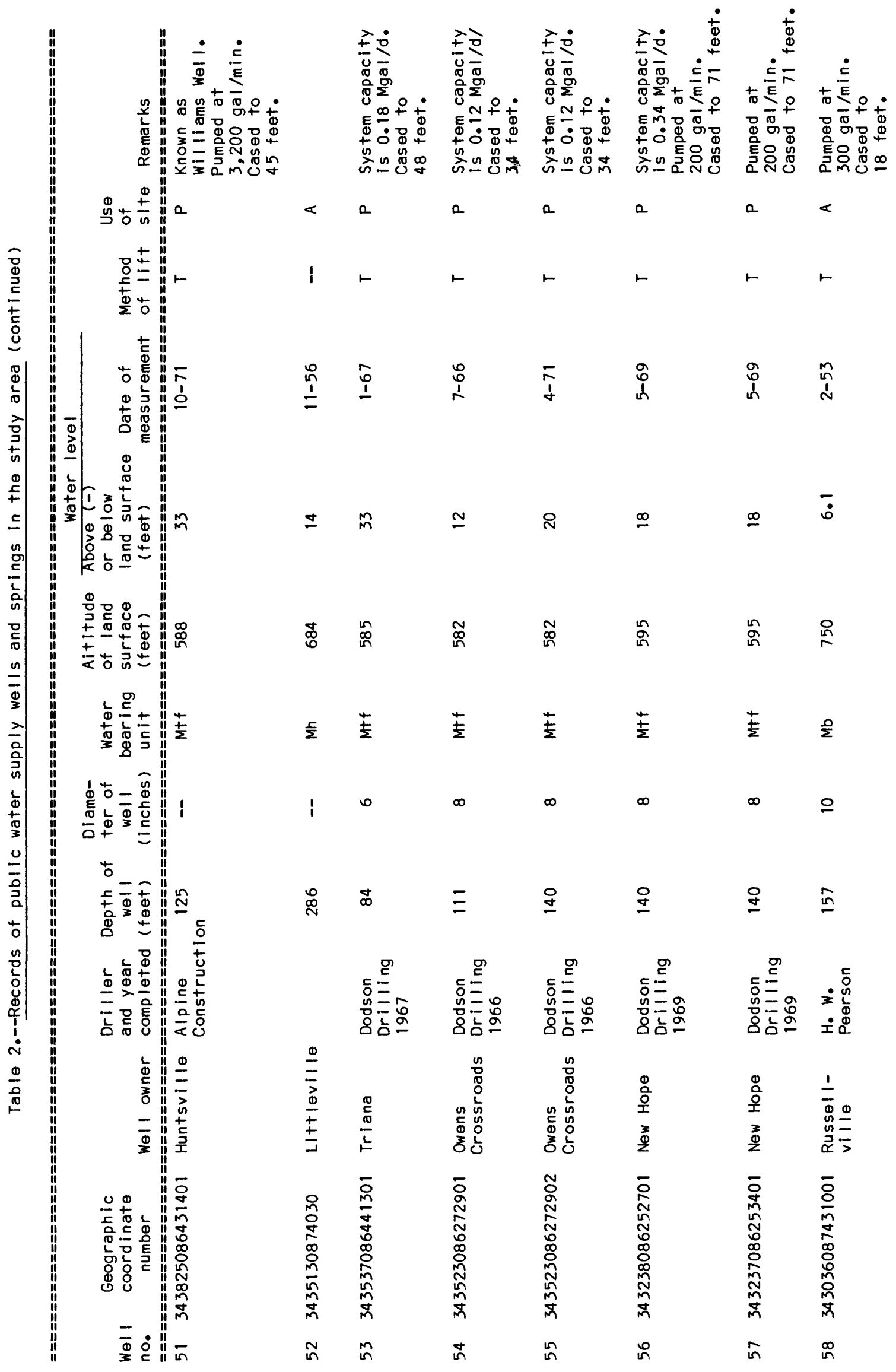




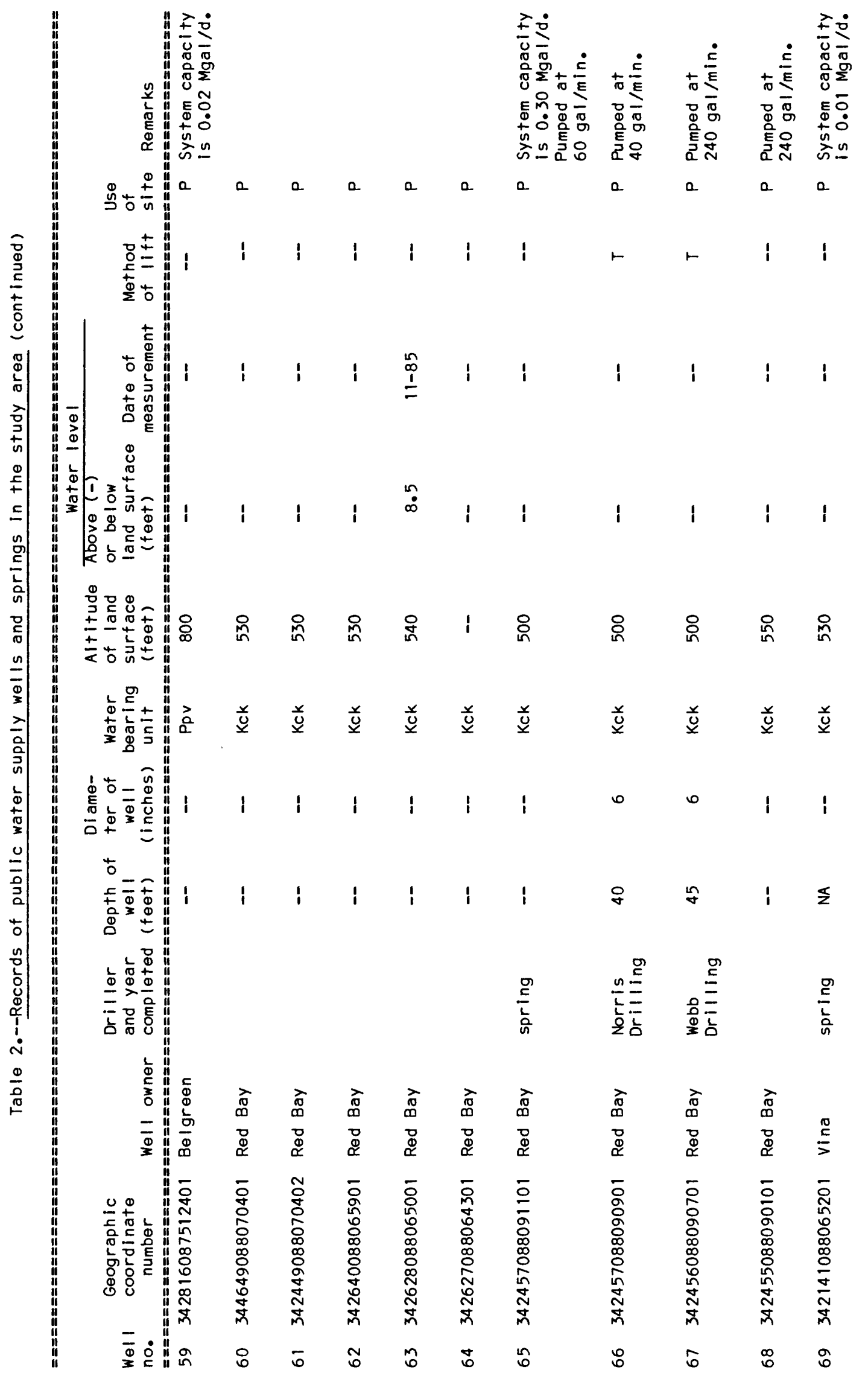




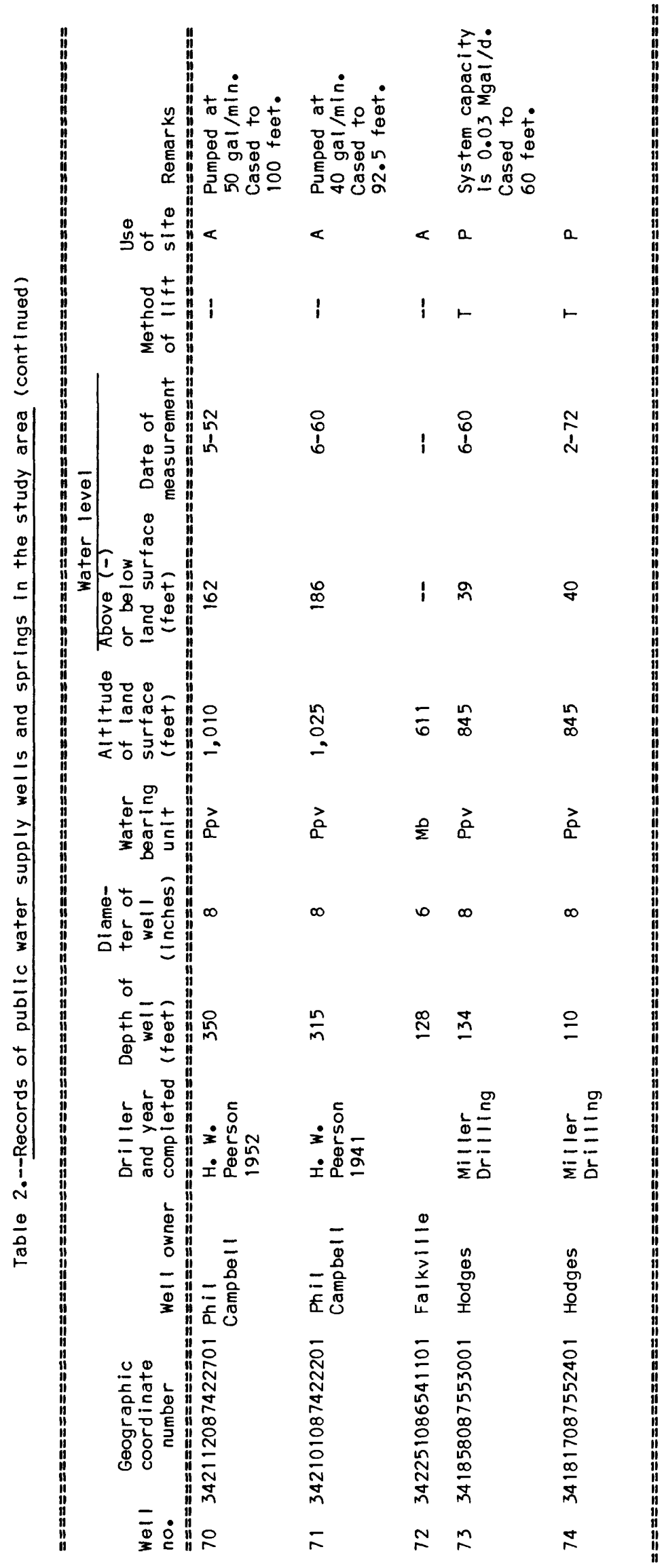


Table 3.--Summary of potentiometric surface data base by county

\begin{tabular}{|c|c|c|}
\hline $\begin{array}{l}\text { County name } \\
===========\end{array}$ & 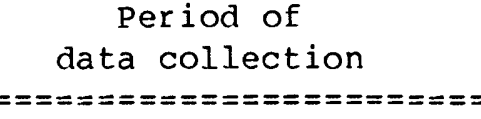 & 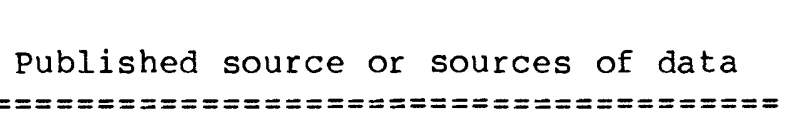 \\
\hline Colbert & $\begin{array}{l}\text { December } 10,1958 \text { to } \\
\text { December } 11,1958\end{array}$ & $\begin{array}{l}\text { Harris, Moore, and West (1963) } \\
\text { (modified to include Tuscaloosa } \\
\text { data) }\end{array}$ \\
\hline Franklin & $\begin{array}{l}\text { miscellaneous measure- } \\
\text { ments } 1955-63\end{array}$ & Peace (1963) \\
\hline Lauderdale & $\begin{array}{l}\text { December } 10,1958 \text { to } \\
\text { December } 11,1958\end{array}$ & Harris, Peace, and Harris (1963) \\
\hline Lawrence & $\begin{array}{l}\text { miscellaneous measure- } \\
\text { ments } 1955-63\end{array}$ & Harris and McMaster (1965) \\
\hline Limestone & $\begin{array}{l}\text { miscellaneous measure- } \\
\text { ments } 1955-63\end{array}$ & McMaster (1960) \\
\hline Madison & $\begin{array}{l}\text { miscellaneous measure- } \\
\text { ments } 1970-74\end{array}$ & $\begin{array}{l}\text { Christensen, Faust, and Harris } \\
\text { (1975) }\end{array}$ \\
\hline Morgan & $\begin{array}{l}\text { miscellaneous measure- } \\
\text { ments } 1955-63\end{array}$ & Dodson and Harris (1965) \\
\hline
\end{tabular}

